\title{
Bermain Sebagai Sarana Mengembangkan Keterampilan Menyimak Anak Usia Dini
}

\author{
Vina Anggia Nastitie Ariawan ${ }^{1}$, Eka Dwi Agustin ${ }^{2}$, Rahman $^{3}$ \\ ${ }^{1} \mathrm{SD}$ Negeri Bantarmangu 01 \\ Jalan Gunungtiga, Cimanggu, Cilacap, Indonesia \\ ${ }^{2}$ Pendidikan Guru Sekolah Dasar, STKIP Majenang \\ Jalan Raya Pahonjean Km. 2, Cilacap, Indonesia \\ ${ }_{3}^{3}$ Ipendidikan Bahasa Daerah, Universitas Pendidikan Indonesia \\ Jalan Dr. Setiabudhi Nomor 229 Bandung, Indonesia \\ Email: vivianatsir@gmail.com ${ }^{1}$, caca.agustyn@gmail.com ${ }^{2}$, rahmanprofupi@upi.edu ${ }^{3}$
}

Naskah diterima: 14 Desember 2018, direvisi: 10 Januari 2019, diterbitkan: 30 Maret 2019

\begin{abstract}
Abstrak
Bermain memiliki beragam manfaat bagi perkembangan anak usia dini. Salah satu manfaat bermain yaitu untuk mengembangkan keterampilan berbahasa seperti menyimak. Menyimak merupakan aspek berbahasa yang dominan dipakai dalam aktivitas sehari-hari. Namun, pembelajaran menyimak kerap tidak mendapat perhatian serius padahal daya simak sangat berpengaruh terhadap pemahaman suatu materi yang disampaikan secara lisan. Penelitian ini bertujuan untuk mengembangkan keterampilan menyimak anak usia dini melalui kegiatan bermain. Penelitian menerapkan penelitian tindakan dengan desain model Lewin. Penelitian dilaksanakan sebanyak empat pertemuan. Penelitian melibatkan 15 anak sebagai partisipan. Penelitian berlokasi di salah satu Taman Kanak-kanak kecamatan Majenang. Teknik pengumpulan data dalam penelitian menggunakan observasi dan tes sedangkan data dianalisis melalui analisis tematik. Sementara itu, uji validitas data menggunakan teknik triangulasi. Hasil penelitian mengindikasikan bahwa bermain dapat mengembangkan keterampilan menyimak anak. Berdasarkan hasil penelitian, maka peneliti menyimpulkan bahwa bermain dapat menjadi salah satu sarana dalam pengembangan keterampilan menyimak anak usia dini.
\end{abstract}

Kata kunci: anak, bahasa, bermain, menyimak

\author{
Abstract \\ Playing activity has various advantages for early childhood development. One of playing's advantages is to \\ building language skill such as listening skill. Listening is one of language aspects which used on daily activities \\ frequently. Nevertheless, listening often does not get serious attention eventhough listening skill is very
}


influential on understanding a material that is delivered orally. Consequently, the purpose of this research is to develop early childhood's listening skill by playing activities. This research employed action research within Lewin's model design. This research was done in four cycles. In addition, 15 children involved as the research participants and it is located at one of kindergarten in Majenang Sub-district. Techniques of collecting data involved observation and listening skill test meanwhile the data analyzed by thematic analysis. Moreover, the data validated by using triangulation technique. Result of this research showed that playing activities can develop children's listening skill. As result of this research, researcher concludes that playing activities can be one of facility to develop early childhood's listening skill.

Keywords: children, languages, listening, playing

\section{Pendahuluan}

Mengembangkan keterampilan berbahasa perlu dilakukan sejak anak memasuki usia prasekolah. Usia prasekolah biasanya dilalui anak dengan mengenyam Pendidikan Anak Usia Dini. Pendidikan Anak Usia Dini pada hakikatnya adalah pendidikan yang diselenggarakan dengan tujuan memfasilitasi pertumbuhan dan perkembangan anak secara menyeluruh atau menekankan pada pengembangan aspek kepribadian anak. Oleh karena itu, Pendidikan Anak Usia Dini memberi kesempatan kepada anak untuk mengembangkan kepribadian dan potensi secara maksimal (Suyadi \& Ulfah, 2013).

Keterampilan berbahasa merupakan keterampilan dasar yang telah dimiliki anak. Bahasa merupakan bentuk utama mengekspresikan pikiran dan pengetahuan ketika anak mengadakan kontak dengan orang lain. Anak yang tengah mengalami tumbuh kembang akan mengomunikasikan kebutuhan, pikiran, dan perasaan melalui bahasa dengan kata-kata yang mempunyai makna. Perkembangan bahasa anak usia dini seiring dengan perkembangan kognitifnya (Gulec \& Durmus, 2015). Kemampuan anak usia dini untuk memahami bahasa orang lain masih terbatas. Anak usia dini pada umumnya hanya memahami bahasa dari persepsi dirinya sendiri. Meskipun demikian, terdapat anak usia dini yang mengalami akselerasi perkembangan bahasa yang disebabkan oleh perkembangan fungsi simbolis. Apabila fungsi simbolis telah berkembang dengan baik maka akan memperluas kemampuan memecahkan persoalan dengan belajar dari bahasa orang lain.

Masa awal kehidupan anak sudah belajar mendengar sehingga mereka dapat meniru ujaran yang diucapkan oleh orang sekitarnya. Oleh sebab itu, sejak anak belum mampu berinteraksi mereka perlu diperdengarkan dengan ujaran yang positif agar setiap ujaran yang 
terekam dapat menjadi ingatan yang baik untuk anak. Bertemali dengan pernyataan tersebut, Ariawan \& Pratiwi (2018) menerangkan bahwa anak merekam semua percakapan yang ditujukan pada dirinya sehingga ia akan mengucapkan kosa kata yang telah terekam ketika belajar berbicara. Keterampilan berbahasa selalu berkaitan dengan aktivitas yang dijalankan sehari-hari sehingga keterampilan berbahasa perlu dikembangkan secara terus menerus.

Bahasa berperan sebagai alat untuk mengungkapkan ekspresi dan keinginan dalam berkomunikasi. Terdapat empat aspek keterampilan berbahasa yang meliputi keterampilan menyimak, berbicara, membaca dan menulis. Aspek yang pertama dimiliki anak yaitu keterampilan menyimak. Hal ini sebagaimana pemaparan Oduoluwo \& Oluwakemi (2014) yang menyatakan bahwa menyimak adalah keterampilan bahasa pertama anak yang berkembang dan keterampilan yang paling dominan digunakan dalam kehidupan sehari-hari. Keterampilan menyimak berperan vital bagi perkembangan anak usia dini. Keterampilan menyimak meskipun tidak menunjukkan keluaran yang tampak akan tetapi keterampilan ini menjadi salah satu faktor keberhasilan anak dalam perkembangannya. Segala aktivitas anak berkaitan dengan keterampilan menyimak. Anak belajar berbicara melalui simakan begitu juga respons yang ditunjukkan anak berdasarkan hasil simakan.

Keterampilan menyimak menjadi bagian dari aspek perkembangan bahasa anak usia dini. Dalam Peraturan Menteri Pendidikan Nasional Nomor 137 Tahun 2014, tentang Standar Nasional PAUD membahas bahwa perkembangan bahasa anak usia 4-5 tahun meliputi menyimak perkataan orang lain, mengerti dua perintah, dan memahami cerita yang dibacakan. Lebih lanjut, Standar Tingkat Pencapaian Perkembangan Anak (STPPA) yang terdapat di dalam Permendikbud No. 146 Tahun 2014 menjabarkan bahwa anak usia 5-6 tahun sudah mampu menceritakan kembali apa yang ia dengar dan melaksanakan perintah yang lebih kompleks sehingga secara tidak langsung keterampilan menyimak berpengaruh pada cara berkomunikasi anak. Anak dikategorikan aktif menyimak bila mampu merespons dan menaruh perhatian pada ujaran yang mereka dengar. Menyimak merupakan proses aktif yang melibatkan aktivitas mendengar, memahami, dan mengintegrasikan informasi sehingga memunculkan suatu respons.

Namun, penekanan yang kurang dalam pembelajaran keterampilan menyimak telah menyebabkan beberapa hambatan yang dihadapi oleh anak. Rendahnya keterampilan menyimak menyebabkan anak kurang memahami ujaran yang didengarkan, ditambah kurangnya bantuan visual berdampak pada munculnya gejala frustasi pada diri anak (Kusuma, Wayuningsih, \& Syamsuddin, 2016). Gejala frustasi yang muncul pada anak menjadikan ia 
sulit berkonsentrasi sehingga tidak dapat memerhatikan pembelajaran dengan baik. Sejalan dengan itu, Renukadevi (2014) memaparkan bahwa keterampilan menyimak yang kurang maksimal mengakibatkan tujuan pembelajaran tidak tercapai secara efektif.

Robinshaw (2007) juga menerangkan bahwa meskipun fisik anak sedang dalam keadaan prima tetapi tidak didukung oleh lingkungan yang kondusif seperti kebisingan maka pengembangan keterampilan menyimak menjadi kurang optimal. Begitu pula jika kondisi fisik dan lingkungan sudah memadai tetapi anak memiliki pengalaman berbahasa yang sedikit maka pembelajaran menyimak tidak berjalan dengan efektif. Terlebih jika pembelajaran menyimak kurang mendapat perhatian oleh guru karena fokus guru hanya pada melatih anak untuk menulis atau mengenal huruf. Selain itu, persepsi dari guru bahwa pembelajaran hanya berkaitan dengan aktivitas yang serius menyebabkan pembelajaran berlangsung di dalam kelas. Padahal pembelajaran menyimak dapat diintegrasikan dengan kegiatan bermain.

Bagi anak bermain adalah kegiatan yang serius tetapi menyenangkan. Menurut Montessori (2013) pembelajaran yang sejati muncul dari kebebasan anak-anak untuk memilih kegiatan mereka. Bermain adalah aktivitas yang dipilih sendiri oleh anak karena menyenangkan, bukan karena hadiah atau pujian. Melalui bermain, semua aspek perkembangan anak dapat ditingkatkan. Anak dapat bereksplorasi untuk memperkuat hal yang sudah diketahui dan menemukan hal baru ketika bermain (Brooker, 2017). Selain itu, anak juga dapat mengembangkan semua potensinya secara optimal, baik potensi fisik maupun mental intelektual dan spiritual. Oleh karena itu, bermain bagi anak usia dini merupakan jembatan bagi berkembangnya semua aspek.

Bermain biasanya identik dengan pengembangan aspek kognitif dan psikomotor anak. Hal ini disebabkan bermain melibatkan aktivitas fisik dan kognitif. Ketika bermain anak akan mengerahkan imajinasi serta menciptakan suatu interaksi. Ketika berinteraksi secara tidak langsung anak akan belajar menggunakan keterampilan berbahasa. Dengan demikian, bermain tidak selalu relevan dengan perkembangan aspek kognitif dan psikomotor anak tetapi dapat mengembangkan keterampilan berbahasa anak. Anak akan belajar mendengar percakapan teman sebayanya ketika bermain dan ia belajar untuk mengemukakan pendapatnya (Brown, 2017). Salah satu strategi yang biasa digunakan guru untuk meningkatkan keterampilan berbahasa khususnya berbicara yaitu bermain peran. Melalui bermain peran anak secara alami akan belajar untuk menyimak dan berbicara sehingga kedua keterampilan berbahasa mereka semakin berkembang. 
Penelitian ini memanfaatkan kegiatan bermain untuk mengembangkan keterampilan menyimak anak usia dini. Penelitian ini bertitik tolak pada penelitian sebelumnya yang telah dilakukan oleh Ariawan (2016) yang mengimplementasikan metode permainan dalam peningkatan keterampilan menyimak siswa kelas I sekolah dasar. Permainan yang digunakan dalam peningkatan keterampilan menyimak berupa metode permainan what is it berbantuan media gambar. Dalam permainan ini, siswa menyimak teka-teki yang disampaikan guru kemudian siswa menjawab pertanyaan dengan memilih gambar. Hasil penelitian mengindikasikan bahwa metode permainan what is it dapat meningkatkan keterampilan menyimak siswa kelas I. Merujuk pada penelitian sebelumnya, peneliti menyimpulkan bahwa metode permainan dapat menjadi salah satu cara dalam peningkatan keterampilan menyimak.

Metode permainan dan bermain merupakan kegiatan yang saling terkait. Dalam bermain terdapat metode permainan yang diimplementasikan untuk meningkatkan berbagai aspek perkembangan anak usia dini. Berdasarkan permasalahan serta penelitian terdahulu, maka peneliti melakukan penelitian yang bertujuan untuk mengembangkan keterampilan menyimak anak usia dini melalui aktivitas bermain.

\section{Metodologi}

Penelitian tindakan terpilih sebagai metode yang digunakan dalam penelitian ini. Penelitian tindakan adalah penelitian yang berfokus pada upaya untuk meningkatkan mutu kehidupan melalui perbaikan atau peningkatan praktik dalam profesi tertentu sehingga dapat mencapai hasil yang efektif dan efisien (Reason \& Badburry, 2001). Penelitian tindakan ini menerapkan model Lewin yang dimulai dengan munculnya gagasan awal untuk memperbaiki suatu praktik tertentu kemudian diikuti dengan pengumpulan data awal, menyusun rencana tindakan yang sesuai, lalu melakukan upaya perbaikan.

Model Lewin merumuskan penelitian dengan tahap perencanaan, tahap implementasi, tahap evaluasi, dan kembali ke tahap awal hingga penelitian mencapai suatu tingkat pencapaian yang diinginkan (Suharsaputra, 2014). Penelitian tindakan dilaksanakan sebanyak empat pertemuan dengan 15 anak sebagai partisipan penelitiannya. Penelitian ini berlokasi di salah satu Taman Kanak-kanak kecamatan Majenang. Adapun teknik pengumpulan data dalam penelitian melibatkan teknik observasi dan tes keterampilan menyimak. Peneliti berperan sebagai partisipan pasif artinya peneliti tidak terlibat dalam pembelajaran. Peneliti hanya mengamati aktivitas dan menilai tes yang dilakukan anak. Peneliti mencatat jalannya 
pembelajaran dan hal-hal menarik yang sekiranya penting untuk dicantumkan dalam penelitian. Sementara itu, tes keterampilan menyimak dilakukan dengan suasana yang santai sehingga anak tidak merasa sedang dinilai. Dengan demikian, hasil yang ditunjukkan tidak mengada-ada.

Selanjutnya, teknik analisis data menggunakan analisis tematik. Peneliti menyiapkan hasil observasi untuk mengklasifikasi suatu kategori dan kode. Kode-kode tersebut nantinya diinterpretasi sehingga menghasilkan data yang membenarkan atau menyangkal praduga peneliti (Creswell, 2016). Kemudian peneliti memilih teknik triangulasi untuk validitas data. Triangulasi merujuk pada pengumpulan informasi sebanyak mungkin dari berbagai sumber melalui berbagai metode (Cohen, Manion, \& Marison, 2011). Penelitian ini menggunakan triangulasi jenis data yang diperoleh dari catatan lapangan dan analisis hasil tes. Penelitian menetapkan indikator keberhasilan sebanyak 85\%.

\section{Hasil dan Diskusi}

Penelitian dilaksanakan sebanyak empat kali pertemuan. Setiap pertemuan mengimplementasikan permainan menyimak yang berbeda. Hasil penelitian dapat dilihat pada Gambar 1 berikut.

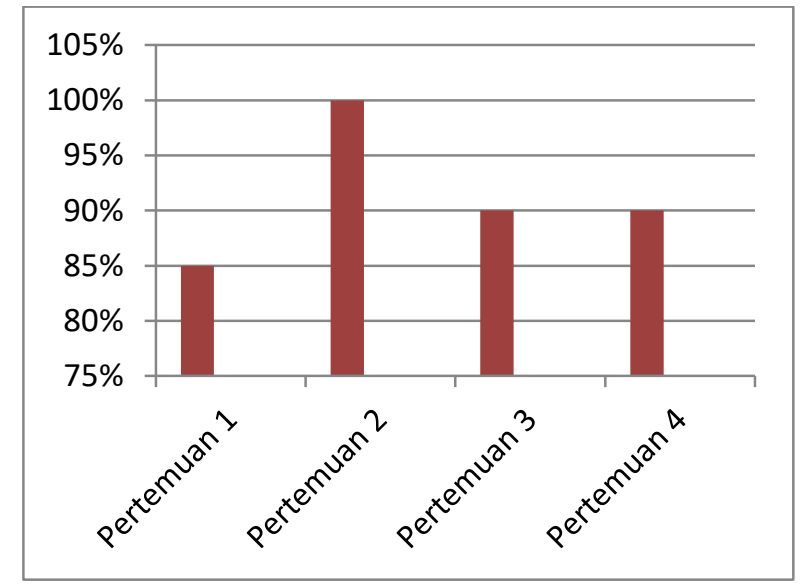

Gambar 1. Grafik Hasil Keterampilan Menyimak

Pertemuan 1 anak bermain mengangkat kertas warna sesuai instruksi. Dalam permainan ini, setiap anak memegang dua kertas berwarna yang berbeda. Guru memberi instruksi kuning di tangan kanan-biru di tangan kiri. Anak harus mengangkat kertas warna 
sesuai dengan instruksi. Bila anak tidak memperoleh kertas warna yang disebutkan guru maka ia tidak perlu mengangkat kertas warnanya. Permainan ini membutuhkan konsentrasi yang baik dan melibatkan keterampilan menyimak anak. Pertemuan pertama ketuntasan anak mencapai 85\%, dari 15 anak hanya 3 anak yang belum bisa mengikuti permainan dengan baik. Anak masih kesulitan menentukan posisi kertas warna di tangan kanan atau tangan kiri.

Pertemuan 2 anak bermain memindahkan kertas warna sesuai instruksi. Anak terbagi menjadi dua kelompok kemudian bermain memindahkan kertas warna secara bergilir. Anak akan berlari dari ujung ke ujung, mengambil kertas yang diinstruksikan, lalu kembali ke tempat ia mengantre giliran. Permainan ini dapat mengembangkan daya ingat anak karena selama berlari ia harus mengingat kertas warna yang diambil. Permainan ini berjalan dengan baik, semua anak dapat menyelesaikan permainan dan melakukan instruksi yang sesuai. Pada pertemuan dua ketuntasan tes menyimak anak mencapai hasil yang sempurna yaitu $100 \%$. Pencapaian ini disebabkan permainan mudah diikuti anak. Meskipun permainan sangat sederhana tetapi dapat melatih daya simak mereka.

Pertemuan 3 anak bermain melompati kertas warna. Guru menyiapkan kertas warna dan meletakkan di lantai secara acak. Anak harus melompati kertas warna yang disebut guru. Sebagai contoh, guru menyebut warna merah muda maka anak harus melompat ke kertas berwarna merah muda. Selain melatih daya simak anak, permainan ini melatih kerja motorik anak. Hasil pertemuan 3 mencapai 90\% karena terdapat dua anak yang belum mampu mengikuti instruksi. Anak masih kesulitan membedakan warna, hal ini menjadi perhatian guru bahwa setiap anak memiliki kemampuan yang berbeda.

Pertemuan 4 atau pertemuan akhir anak bermain melompati kertas warna sambil menyebut angka yang tertera pada kertas. Anak melompati kertas dan menyebut angka pada kertas yang ia lompati. Permainan ini tidak hanya untuk melatih daya simak akan tetapi dapat diintegrasikan dengan materi belajar yang lain seperti pengenalan angka. Hasil pertemuan 4 serupa dengan hasil pertemuan sebelumnya yaitu 90\%. Dua anak belum mengikuti instruksi yang sesuai. Anak tampak kesulitan berkonsentrasi karena harus melompati warna sesuai instruksi dan menyebut angka.

Berdasarkan penjelasan sebelumnya, maka peneliti menyimpulkan bahwa hasil penelitian telah mencapai indikator keberhasilan yang ditetapkan sehingga aktivitas bermain dapat menjadi satu alternatif untuk mengembangkan keterampilan menyimak anak usia dini. Perkembangan bahasa merupakan salah satu dari enam lingkup perkembangan yang harus dibina pada anak usia dini. Pengembangan materi pembelajaran yang menyangkut bahasa 
anak sangat penting karena berpengaruh dalam peningkatan kemampuan komunikasi anak sesuai dengan tahapan usianya. Selain itu, adanya pembelajaran bahasa bertujuan agar anak dapat bersosialisasi dengan orang-orang yang ada di sekitarnya (Sumartini, 2016).

Upaya guru untuk mengembangkan bahasa pada anak usia dini diimplementasi dalam proses pembelajaran di kelas dengan materi pembelajaran bahasa yang selaras dengan lingkup perkembangan anak. Dalam penelitian ini, peneliti mengajak anak untuk melakukan permainan yang bermanfaat untuk mengembangkan keterampilan menyimaknya. Dalam permainan ini, anak belajar untuk memahami bahasa dengan cara mengikuti instruksi yang dipaparkan guru. Hal ini sejalan dengan penelitian sebelumnya oleh Widyastuti (2018) tentang upaya guru dalam pengembangan bahasa anak usia dini. Salah satu upaya yang dilakukan guru yaitu mengajarkan anak untuk memahami bahasa dengan cara memerintahkan anak untuk berlari, melompat, mengamati gambar, pesan berantai, dan bermain ular naga. Upaya yang dilakukan guru menunjukkan bahwa mengembangkan keterampilan berbahasa dapat dilakukan dengan aktivitas bermain.

Salah satu fungsi penting bermain menurut Piaget ialah memberikan kesempatan kepada anak untuk mengasimilasi kenyataan terhadap dirinya dan dirinya terhadap kenyataan. Sebagai implikasi dari beberapa konsep tentang pentingnya bermain terhadap pembelajaran anak usia dini adalah menciptakan lingkungan belajar yang memungkinkan anak dapat belajar sambil bermain dan bermain seraya belajar secara efektif (Holis, 2016). Sejalan dengan itu, Musbikin (2010) mengatakan bahwa anak berkembang dengan cara bermain karena bermain merupakan dunia anak. Melalui aktivitas bermain, anak-anak akan menggunakan otot tubuhnya, menstimulasi indera tubuhnya, mengeksplorasi dunia sekitar, menemukan karakteristik lingkungan yang ia tinggali, dan menemukan karakteristik dirinya sendiri sendiri. Di samping itu, anak akan menemukan dan mempelajari berbagai hal atau keahlian baru dan belajar menggunakan keahlian di waktu yang tepat, serta memuaskan apa yang menjadi kebutuhannya. Melalui bermain kondisi fisik, kemampuan kognitif, dan keterampilan berbahasa anak akan terlatih serta berkembang (Musbikin, 2010).

Melatih keterampilan menyimak melalui aktivitas bermain dikategorikan sebagai interior listening dan visible listening. Interior listening adalah kegiatan menyimak yang berkaitan dengan pemahaman bahasa, artinya anak dapat memahami serta melakukan tindakan atas ujaran yang diucapkan oleh orang lain (Jalongo, 2010). Dalam penelitian ini, anak melakukan tindakan sesuai dengan instruksi guru. Anak-anak sudah dapat memahami bahasa yang diucapkan guru sehingga mereka dapat melakukan tindakan sesuai instruksi. Kemudian visible listening 
merupakan kegiatan menyimak yang memanfaatkan alat bantu berupa media gambar, alat peraga, atau benda konkret untuk dijadikan bahan diskusi dan seringnya juga berperan untuk melengkapi kegiatan interior listening (Jalongo, 2010). Dalam penelitian ini, visible listening ditunjukkan dengan cara anak memainkan kertas warna sesuai instruksi guru.

Sementara itu, menurut Mulyasa (2012) jenis-jenis bermain yang dapat digunakan sebagai metode pembelajaran bagi anak usia dini yaitu bermain sosial, bermain dengan benda, dan bermain peran. Dalam bermain sosial, guru berperan mengamati cara bermain anak dan dia akan memperoleh kesan bahwa partisipasi anak dalam kegiatan bermain dengan temantemannya akan menunjukkan derajat partisipasi yang berbeda. Kemudian, bermain dengan benda merupakan kegiatan bermain ketika anak dalam menggunakan atau mempermainkan benda-benda tertentu dapat menjadi hiburan yang menyenangkan. Tipe bermain dengan benda meliputi bermain praktis, bermain simbolik, dan bermain dengan aturan. Selanjutnya, bermain peran bermanfaat bagi anak untuk mengekplorasi hubungan antarmanusia dengan cara memperagakannya sehingga mereka dapat mengekplorasi perasaan, sikap, nilai, dan berbagai strategi pemecahan masalah yang kerap muncul dalam kehidupan. Merujuk pada penjelasan sebelumnya, maka jenis bermain yang dilaksanakan dalam penelitian ini berupa bermain benda dengan aturan.

Selanjutnya, terdapat tiga anak yang belum mengikuti instruksi guru sehingga mereka kurang mampu melaksanakan permainan dengan maksimal. Kurangnya kemampuan anak dalam pelaksanaan permainan dapat disebabkan oleh beberapa faktor seperti faktor fisik dan pengalaman linguistik anak. Dilihat dari faktor fisik, dua anak memiliki kondisi fisik yang kurang energik sehingga mereka cukup lamban ketika mengikuti permainan. Sementara itu, ditinjau dari pengalaman linguistik anak mereka perlu diberi bimbingan karena guru harus menggunakan bahasa ibu agar anak dapat memahami jalannya permainan. Hal ini sebagaimana dipaparkan oleh Edele \& Stanat (2016) yang menjelaskan bahwa anak usia dini perlu belajar untuk membangun konsentrasi melalui kegiatan menyimak. Bila anak terbiasa menyimak maka ia akan mempunyai daya simak yang baik yang berperan sebagai faktor penunjang dalam pemahaman materi belajar.

Rendahnya keterampilan menyimak dapat disebabkan berbagai hal seperti kondisi fisik anak yang sedang kurang baik atau pembelajaran menyimak yang kurang variatif. Lebih lanjut Nelson, dkk. (2005) memaparkan bahwa terdapat tiga domain penting yang perlu diperhatikan guru dalam aktivitas menyimak anak usia dini yakni (1) faktor fisik anak terutama pada bagian indera pendengaran; (2) kejelasan suara dan suasana lingkungan; (3) 
pengalaman linguistik anak yang beragam. Tiga domain tersebut dapat menghambat proses pengembangan keterampilan menyimak anak.

Keterampilan menyimak yang berkembang melalui kegiatan bermain mengindikasikan bahwa keterampilan menyimak anak berada dalam tahap Understanding. Understanding atau memahami merupakan proses aktif menyimak sehingga anak dapat memahami informasi yang disampaikan oleh guru atau orang yang tengah berbicara (Bourdeaud'hui, dkk., 2018). Tahap memahami merupakan tahap yang lebih tinggi dari mendengar. Memahami simakan sederhana seperti instruksi dari guru atau teman sebaya.

Keterampilan menyimak berperan penting dan merupakan bekal bagi keberhasilan akademik anak ketika memasuki tahap sekolah. Melalui keterampilan menyimak anak dapat memperoleh pengetahuan secara langsung yang dipaparkan oleh guru. Pemahaman materi tidak terlepas dari peran guru yang menerangkan materi secara langsung. Meskipun penggunaan media pembelajaran membantu akan tetapi anak tetap membutuhkan penjelasan dari guru. Bila anak dapat menyimak dengan baik maka mereka dapat menerima, menalar, dan menghubungkan informasi baru dengan informasi lama.

\section{Penutup}

Keterampilan menyimak dikategorikan sebagai keterampilan berbahasa yang bersifat reseptif. Dikategorikan reseptif karena keterampilan ini tidak menampakkan aktivitas untuk memproduksi suatu produk bahasa. Meskipun bersifat reseptif akan tetapi keterampilan menyimak merupakan dasar dari penguasaan keterampilan berbahasa lainnya bahkan menjadi faktor yang berpengaruh terhadap kemampuan kognitif atau kemampuan bersosialisasi. Oleh sebab itu, keterampilan menyimak perlu dilatih sejak dini karena keterampilan ini berkaitan dengan ketahanan konsentrasi anak. Satu dari sekian banyak upaya untuk mengembangkan keterampilan menyimak yaitu melalui Pendidikan Anak Usia Dini.

Pendidikan Anak Usia Dini berperan untuk memfasilitasi perkembangan anak. Mengembangkan keterampilan menyimak dapat dilakukan melalui aktivitas bermain. Bermain adalah dunia anak, ketika anak belajar tidak dikondisikan dengan bermain maka secara tidak langsung mereka akan kehilangan dunianya. Salah satu tujuan pembelajaran menyimak pada anak usia dini di antaranya yaitu agar mereka dapat memahami isi cerita atau mengikuti perintah sederhana. Aktivitas bermain dalam penelitian ini berupa bermain benda dengan bimbingan. Anak akan melakukan tindakan berdasarkan instruksi guru. Ketika anak 
dapat mengikuti instruksi guru maka keterampilan menyimaknya sudah mulai berkembang dengan baik. Dalam penelitian ini, hampir semua anak dapat mengikuti permainan yang diinstruksikan guru. Berdasarkan hasil penelitian, maka peneliti menyimpulkan bahwa aktivitas bermain dapat menjadi salah satu sarana untuk mengembangkan keterampilan menyimak anak usia dini.

\section{Daftar Pustaka}

Ariawan, V.A.N. (2016). Penerapan metode permainan what is it dengan media gambar dalam peningkatan keterampilan menyimak di kelas 1 sekolah dasar. Dalam Prosiding Seminar Nasional Inovasi Pendidikan: Inovasi pembelajaran berbasis karakter dalam menghadapi Masyarakat Ekonomi ASEAN, 181-192. Surakarta: Universitas Sebelas Maret.

Ariawan, V.A.N., \& Pratiwi, I.M. (2018). Dialogic reading sebagai upaya mengembangkan keterampilan berbahasa anak usia dini. JAPRA, I (1), 79-86.

Brooker, L. (2017). Learning to play, or playing to learn? Children's participation in the cultures of homes and settings. Dalam buku Young Children's Play and Creativity,14-25. London: Routledge.

Brown, G. (2017). Listening to spoken english. London: Routledge.

Bourdeaud'hui, H., dkk. (2018). Identifying student and classroom characteristics related to primary school students' listening skills: A systematic review. Educational Research Review. Article Inpress.

Cohen, L., Manion, L., \& Marrison, K. (2011). Research in education sixth edition. Newyork: Routledge.

Creswell, J.W. (2016). Research design: Pendekatan kualitatif, kuantitatif, dan campuran. Yogyakarta: Pustaka Pelajar.

Edele, A., \& Stanat, P. (2016). The role of first language listening comprehension in second language reading comprehension. Journal of Education Psychology, 108 (2), 163-170.

Gulec, S., \& Durmus, N. (2015). A study aiming to develop listening skills of elementary second grade students. Procedia-Social and Behavioral Sciences, 191, 103-109.

Holis, A. (2016). Belajar melalui bermain untuk pengembangan kreativitas dan kognitif anak usia dini. Jurnal Pendidikan Universitas Garut, 9 (1), 23-37.

Jalongo, M.R. (2010). Listening in early childhood: An interdisciplinary review of the literature. International Journal of Listening, 24 (1), 1-18.

Kusuma, A., Wahyuningsih, S., \& Syamsuddin, M.M. (2016). Efektivitas metode read aloud terhadap keterampilan menyimak anak usia 5-6 tabun. Surakarta: Universitas Sebelas Maret. Diakses dari https://journal.fkip.uns.ac.id.

Montessori, M. (2013). The origin of an educational innovation: Including an abridged and annotated edition of maria montessori`s the montessori method. Yogyakarta: Pustaka Pelajar. 
Mulyasa, E. (2012). Manajemen PAUD. Bandung: Remaja Rosdakarya.

Musbikin, I. (2010). Buku Pintar PAUD (dalam Perspektif Islam). Yogyakarta: Laksana.

Nelson, P., dkk. (2005). Classroom noise and children learning through a second language: Double jeopardy? Language, Speech, and Hearing Services in Schools, 36, 219-229.

Oduolowu, E., \& Oluwakemi, E. (2014). Effect of storytelling on listening skills of primary one pupil in Ibadan North Local Goverment Area on Oyo State, Nigeria. International Journey of Humanities and Social Science, 4 (9), 100-107.

Reason. P., \& Bradburry, H. (2001). Handbook of action research. New York: Sage Publication.

Renukadevi, D. (2014). The role of listening in language acquistion: The vhallenges \& strategies in teaching listening. International Journal of Education and Information Studies, 4 (1), 59-63.

Robinshaw, H. (2007). Acquisition of hearing, listening and speech skills by and during Key Stage 1. Early Child Development \& Care, 177 (6/7), 661-678

Suharsaputra, U. (2014). Metode penelitian kuantitatif, kualitatif, dan tindakan. Bandung: Refika Aditama.

Sumartini, E. U. (2016). Modul guru pembelajar taman kanak-kanak kelompok kompetensi F, Pedagogik: Media dan sumber belajar di TK, profesional: bermain sambil belajar di TK . Bandung: PPPPTK TK DAN PB.

Suyadi \& Ulfah, M. (2013). Konsep dasar PAUD. Bandung: Remaja Rosdakarya.

Widyastuti, A. (2018). Analisis upaya guru dalam mengembangkan bahasa pada anak usia 56 Tahun di Taman Kanak-kanak Assaadah Limo Depok. Children Advisory Research and Education, 6 (1), 10-17. 